\title{
Berry bushes in the landscape architecture of urban megacities
}

\author{
Olga Hanbabaeva ${ }^{1, *}$, Dmitry Kalashnikov ${ }^{1}$, Vladimir Sorokopudov ${ }^{3}$, and Anna Matsneva ${ }^{2}$ \\ ${ }^{1}$ Russian State Agrarian University- Moscow Agricultural Academy named after K.A. Timiryazev, \\ Landscape architecture Department, Moscow, Russia \\ ${ }^{2}$ Russian State Agrarian University- Moscow Agricultural Academy named after K.A. Timiryazev, \\ Pomiculture laboratory, Moscow, Russia \\ ${ }^{3}$ Russian State Agrarian University- Moscow Agricultural Academy named after K.A. Timiryazev, \\ Decorative gardening and lawn science Department, Moscow, Russia
}

\begin{abstract}
Along with traditional and popular berry crops in private gardens, there are few common types and decorative forms. The purpose of the research was to expand the range of ornamental shrubs in the landscaping of large Metropolitan areas and to popularize knowledge about new or little-known types of berry bushes. As a result of studies on the value of the adaptation coefficient, the studied shrub species were divided into three groups according to the degree of prospects. The most promising group consisting of $65 \%$ of samples was the first, whose representatives were characterized by high winter hardiness and the ability to complete seed propagation, decorative. The average prospective second group includes $20 \%$ of the studied samples. This includes plants that remain decorative during the growing season, are able to reproduce by seeds, but they are less promising than the representatives of the 1st group, due to the inability to maintain decorativeness in the growing season and do not give offspring by self-seeding. The third group, which was not promising, included $15 \%$ of samples. Species of shrubs belonging to this group are quite hardy, have the ability to seed propagation.
\end{abstract}

\section{Introduction}

Today, one of the priorities of urban planning is to ensure harmonious human development in an urban environment with its high man-made loads. Solving this problem is impossible without increasing the norm of green spaces per resident of megacities [2,15].

The main element of the natural environment in the city are not only trees, but also shrubs. Decorative trees and shrubs are familiar for urban landscaping, but berry shrubs are still little common $[1,7,8]$.

In recent years, berry shrubs are used for greening cities with a decorative purpose, to expand the range. Berry shrubs have a great variety of species, and even more so a huge variety of varieties that can be applied in landscape landscaping. The advantages of this type of landscaping are aesthetics, ecology and cost-effectiveness, as well as the cognitive

\footnotetext{
* Corresponding author : hanbabaeva@yandex.ru
} 
purpose - to familiarize the population with existing species and varieties and especially new breeding products [3-5, 9-12].

\section{Research methods}

Positive success of introduction depends, first of all, on the degree of adaptation of introductions to new environmental conditions $[4,13]$.

To detect adaptability in species of ornamental shrubs to the ecological conditions of megacities, we have applied a method of integral assessment [6-7, 13-17]. The evaluation is based on seven bioecological indicators: winter resistance, gabitus preservation, escapeforming ability, regularity of shoots growth, ability to generative development, possibility of artificial vegetative reproduction, as well as decorativeness [3, 9, 13-14]. These indicators characterize the condition of the plant at the place of introduction and are determined by systematic visual observations. For each indicator, numerical values in points were selected, corresponding to a certain state of the plant. Based on the integral assessment, the total viability score of the shrubs was calculated separately for each year of observations and the average score for the period of observations. Integral numerical expression of the viability of introduced plants is the sum of average scores $[1,9,13,16]$.

\section{Research results}

On the basis of their own research [8-13], a table (table 1) on the use and decorative value of different types of berry and fruit plants in populated areas has been drawn up during the work with berry crops since 1990 and the study of literary sources on the greening of populated areas in Russia's cities and villages. Table 1 presents the main species, varieties and ornamental forms of berry shrubs, which can be used as landscaping of urban gardens and parks. The peculiarity of these cultures is the high decorativeness, unpretentiousness and adaptability to urban conditions, without losing their decorative qualities [2, 9, 10].

Table 1. Promising types of berry shrubs for urban landscaping

\begin{tabular}{|c|c|c|c|}
\hline $\begin{array}{l}\text { Species } \\
\text { name }\end{array}$ & Variety name & $\begin{array}{l}\text { Decorative qualities; } \\
\text { duration of flowering, } \\
\text { vegetation } \\
\text { (days) }\end{array}$ & $\begin{array}{c}\text { Directions use in urban } \\
\text { landscaping } \\
\text { (landing type). } \\
\text { Trouble }\end{array}$ \\
\hline $\begin{array}{l}\text { Cerasus } \\
\text { vulgaris } \\
\text { Mill. }\end{array}$ & $\begin{array}{l}\text { Self-fertile varieties: } \\
\text { Xenia, Nochka, } \\
\text { Vstrecha } \\
\text { Early varieties: } \\
\text { Shokoladnitsa, } \\
\text { Chudo- vishnya } \\
\text { Medium varieties: } \\
\text { Turgenevskaya, } \\
\text { Morozovka } \\
\text { Late varieties: } \\
\text { Lubskaya, } \\
\text { Malinovka } \\
\text { Decorative forms: } \\
\text { f. plena } \\
\text { f. umbraculifera } \\
\text { f. Rexii } \\
\text { f. persicifolia } \\
\text { f. semperflorens } \\
\text { f. aureo-variegata } \\
\end{array}$ & $\begin{array}{l}\text { Decorative: crown, leaf, } \\
\text { bark, tswe-tok, fruit. } \\
\text { Vegetation - April- } \\
\text { September; } \\
\text { Blossoming - May (10-14 } \\
\text { days); } \\
\text { Fertility - June-July; }\end{array}$ & $\begin{array}{l}\text { Solitaire, group, high hedge, } \\
\text { kurtin, ordinary landing. } \\
\text { When a dense planting is } \\
\text { affected by diseases and } \\
\text { pests; } \\
\text { Activities: preventive } \\
\text { treatment, pruning. }\end{array}$ \\
\hline
\end{tabular}




\begin{tabular}{|c|c|c|c|}
\hline $\begin{array}{l}\text { European } \\
\text { dwarf } \\
\text { cherry - } \\
\text { Cerasus } \\
\text { fruticosa } \\
\text { Pall. }\end{array}$ & $\begin{array}{l}\text { Decorative forms: } \\
\text { f. pendula } \\
\text { f. variegata }\end{array}$ & $\begin{array}{l}\text { Decorative: crown, leaf, } \\
\text { bark, flower, fruit. } \\
\text { Vegetation - April- } \\
\text { September; } \\
\text { Blossoming - May (5-12 } \\
\text { days); } \\
\text { Fertility - June; }\end{array}$ & $\begin{array}{l}\text { Solitaire, group, high hedge, } \\
\text { kurtin, ordinary landing. }\end{array}$ \\
\hline $\begin{array}{l}\text { Nanjing } \\
\text { cherry - } \\
\text { Cerasus } \\
\text { tomentosa } \\
\text { (Thunb.) } \\
\text { Wall. }\end{array}$ & $\begin{array}{l}\text { Early varieties: } \\
\text { Natali, Detskaya; } \\
\text { Medium varieties: } \\
\text { Ubileynaya, } \\
\text { Belaya; } \\
\text { Late varieties: } \\
\text { Okeanskaya, } \\
\text { Virovskaya }\end{array}$ & $\begin{array}{l}\text { Decorative: leaf, flower, } \\
\text { fruit. } \\
\text { Vegetation - April- } \\
\text { October; } \\
\text { Blossoming - May (5-10 } \\
\text { days); } \\
\text { Fertility - July; }\end{array}$ & $\begin{array}{l}\text { Group or single planting, } \\
\text { low hedge, kurtin. } \\
\text { Requires wind-protected } \\
\text { places, does not tolerate } \\
\text { heavy, damp soils. }\end{array}$ \\
\hline $\begin{array}{l}\text { Chinese } \\
\text { bush cherry } \\
\text { - Cerasus } \\
\text { glandulosa } \\
\text { (Thunb.) } \\
\text { Loisel. }\end{array}$ & $\begin{array}{l}\text { Rosea, } \\
\text { Terry forms: } \\
\text { Rosea plena, } \\
\text { Alba plena }\end{array}$ & $\begin{array}{l}\text { Decorative: leaf, terry } \\
\text { flower, bark. } \\
\text { Vegetation - May- } \\
\text { October; } \\
\text { Blossoms - June-July; }\end{array}$ & $\begin{array}{l}\text { Solitaire, decorative group, } \\
\text { rocky devices. } \\
\text { Requires wind-protected } \\
\text { places, does not tolerate } \\
\text { heavy, damp soils. }\end{array}$ \\
\hline $\begin{array}{l}\text { Sea- } \\
\text { buckthorn - } \\
\text { Hippohae } \\
\text { rha- } \\
\text { mnoides L. }\end{array}$ & $\begin{array}{l}\text { Altayskaya, } \\
\text { Perchik, } \\
\text { Botanicheskaya, } \\
\text { Vitaminnaya, } \\
\text { Ryabinka, } \\
\text { Botanicheskaya } \\
\text { aromatnaya, } \\
\text { Pamyati Vehova, } \\
\text { Timiryazevsksya } \\
\text { krasavitsa, Parad } \\
\end{array}$ & $\begin{array}{l}\text { Decorative: crown, leaf, } \\
\text { fruit. } \\
\text { Vegetation - May- } \\
\text { September; } \\
\text { Fertility - July-October; }\end{array}$ & $\begin{array}{l}\text { Solitaire, group, curtina, } \\
\text { rank landing. } \\
\text { When planting requires the } \\
\text { edging of the root system, } \\
\text { gives a lot of overgrowth. } \\
\text { Activities: pruning. }\end{array}$ \\
\hline $\begin{array}{l}\text { European } \\
\text { gooseberry, } \\
- \\
\text { Grossularia } \\
\text { reclinata ( } \\
\text { L.) Mill. }\end{array}$ & $\begin{array}{l}\text { Berill, Uralsky } \\
\text { izumrud, } \\
\text { Grushen'ka, } \\
\text { Alladin, Afrikanets, } \\
\text { Kolobok, Laskoviy, } \\
\text { Rodnik, Rozoviy 2, } \\
\text { Sadko, Slavny } \\
\end{array}$ & $\begin{array}{l}\text { Decorative: gabitus, leaf, } \\
\text { fruit. } \\
\text { Vegetation - April- } \\
\text { September; } \\
\text { Blossoming - May (5-7 } \\
\text { days); } \\
\text { Fertility - July; } \\
\end{array}$ & $\begin{array}{l}\text { Solitaire, group, low hedge, } \\
\text { kurtin, ordinary landing. } \\
\text { When a dense planting is } \\
\text { affected by diseases and } \\
\text { pests; } \\
\text { Activities: preventive } \\
\text { treatment, pruning. }\end{array}$ \\
\hline $\begin{array}{l}\text { Golden } \\
\text { currant - } \\
\text { Ribes } \\
\text { aureum } \\
\text { Pursh }\end{array}$ & $\begin{array}{l}\text { Shafak, Venera, } \\
\text { Lyaisan, Businka, } \\
\text { Nahodka, Fatima, } \\
\text { Zarina }\end{array}$ & $\begin{array}{l}\text { Decorative: gabitus, } \\
\text { flowers, leaf, fruit. } \\
\text { Vegetation - April- } \\
\text { October; } \\
\text { Blossoming - May (5-10 } \\
\text { days); } \\
\text { Fertility - July-August }\end{array}$ & $\begin{array}{l}\text { Solitaire, group, low-cut } \\
\text { hedge, curtine, ordinary } \\
\text { planting. }\end{array}$ \\
\hline $\begin{array}{l}\text { American } \\
\text { black } \\
\text { currant - } \\
\text { Ribes } \\
\text { americanu } \\
m \text { Mill. } \\
\end{array}$ & $\begin{array}{l}\text { Sladkoplodnaya, } \\
\text { Missouri, Pluton }\end{array}$ & $\begin{array}{l}\text { Decorative: leaf, flower, } \\
\text { fruit. } \\
\text { Vegetation - May- } \\
\text { October; } \\
\text { Blossoms - May; } \\
\text { Fertility - June-August } \\
\end{array}$ & $\begin{array}{l}\text { Living hedge low, medium, } \\
\text { kurtin, group, private } \\
\text { planting }\end{array}$ \\
\hline
\end{tabular}




\begin{tabular}{|c|c|c|c|}
\hline $\begin{array}{l}\text { Black } \\
\text { currant - } \\
\text { Ribes } \\
\text { nigrum L. }\end{array}$ & $\begin{array}{l}\text { Early varieties: } \\
\text { Ekzotika, Perun } \\
\text { Medium varieties: } \\
\text { Dubrovskaya, } \\
\text { Venera, } \\
\text { Late varieties: } \\
\text { Lentyai, Arcadia }\end{array}$ & $\begin{array}{l}\text { Decorative: leaf, flower, } \\
\text { fruit. } \\
\text { Vegetation - April- } \\
\text { October; } \\
\text { Flowering - April; } \\
\text { Fertility - June; }\end{array}$ & $\begin{array}{l}\text { The hedge is low, medium, } \\
\text { kurtin, group, ordinary } \\
\text { landing. } \\
\text { When a dense planting is } \\
\text { affected by diseases and } \\
\text { pests; } \\
\text { Activities: preventive } \\
\text { treatment, pruning. }\end{array}$ \\
\hline $\begin{array}{l}\text { Red currant } \\
- \\
\text { Ribes } \\
\text { rubrum L. }\end{array}$ & $\begin{array}{l}\text { Early varieties: } \\
\text { Rannyaya sladkaya, } \\
\text { Chulkovskaya } \\
\text { Winter-resistant } \\
\text { varieties: } \\
\text { Uralskaya } \\
\text { krasavitsa, Alaya } \\
\text { zor'ka } \\
\text { Large-fruited } \\
\text { varieties: } \\
\text { Alfa, Baraba } \\
\text { Decorative-leaf } \\
\text { varieties: } \\
\text { Konstantinovskaya }\end{array}$ & $\begin{array}{l}\text { Decorative: gabitus, leaf, } \\
\text { flower, fruit. } \\
\text { Vegetation - April- } \\
\text { October; } \\
\text { Flowering - April; } \\
\text { Fertility - July-August; }\end{array}$ & $\begin{array}{l}\text { Solitaire, hedge low, } \\
\text { middle, kurtin, group, } \\
\text { ordinary landing. } \\
\text { When a dense planting is } \\
\text { affected by diseases and } \\
\text { pests; } \\
\text { Activities: preventive } \\
\text { treatment, pruning. }\end{array}$ \\
\hline $\begin{array}{l}\text { Red } \\
\text { raspberry - } \\
\text { Rubus } \\
\text { idaeus L. }\end{array}$ & $\begin{array}{l}\text { Large-fruited } \\
\text { varieties: } \\
\text { Gerakl, Krasa } \\
\text { Rossii } \\
\text { Remontant } \\
\text { varieties: } \\
\text { Bryanskoe divo, } \\
\text { Jar-ptitsa } \\
\text { Stamp varieties: } \\
\text { Oktavia, Tarusa } \\
\end{array}$ & $\begin{array}{l}\text { Decorative: leaf, flower, } \\
\text { fruit. } \\
\text { Vegetation - April - } \\
\text { September; } \\
\text { Blossoms - June-July; } \\
\text { Fertility - July-August; }\end{array}$ & $\begin{array}{l}\text { Group and solitary landing, } \\
\text { undergrowth. } \\
\text { When a dense planting is } \\
\text { affected by diseases and } \\
\text { pests; } \\
\text { Activities: preventive } \\
\text { treatment, pruning. }\end{array}$ \\
\hline $\begin{array}{l}\text { Black } \\
\text { raspberry - } \\
\text { Rubus } \\
\text { oxidentalis } \\
\text { L. }\end{array}$ & Cumberland & $\begin{array}{l}\text { Decorative: leaf, coloring } \\
\text { shoots, flower, fruit. } \\
\text { Vegetation - April - } \\
\text { September; } \\
\text { Blossoms - June-July; } \\
\text { Fertility - July-August; }\end{array}$ & $\begin{array}{l}\text { Group and solitary landing, } \\
\text { undergrowth. } \\
\text { Requires support } \\
\text { For the winter period } \\
\text { removed from the support. } \\
\text { Requires wind-protected } \\
\text { places, does not tolerate } \\
\text { heavy, damp soils. }\end{array}$ \\
\hline $\begin{array}{l}\text { Flowering } \\
\text { raspberry - } \\
\text { Rubus } \\
\text { odoratus L. }\end{array}$ & $\begin{array}{l}\text { Tridel } \\
\text { Decorative forms: } \\
\text { f. alba }\end{array}$ & $\begin{array}{l}\text { Decorative: leaf, flower, } \\
\text { fruit. } \\
\text { Vegetation - April - } \\
\text { September; } \\
\text { Blossoms - June-July; } \\
\text { Fertility - July-August; }\end{array}$ & $\begin{array}{l}\text { Group and single planting, } \\
\text { jackets, low, medium } \\
\text { hedges }\end{array}$ \\
\hline $\begin{array}{l}\text { Arctic } \\
\text { raspberry - } \\
\text { Rubus } \\
\text { arcticus L. }\end{array}$ & $\begin{array}{l}\text { Anna, Beat, Linda, } \\
\text { Mespi, Mesma, } \\
\text { Pima, Yalamanchin, } \\
\text { Aura, Astra, } \\
\text { Valentina }\end{array}$ & $\begin{array}{l}\text { Decorative: leaf, flower, } \\
\text { fruit. } \\
\text { Vegetation - April - } \\
\text { September; } \\
\text { Blossoms - June-July; } \\
\text { Fertility - July; }\end{array}$ & $\begin{array}{l}\text { Group and solitary planting, } \\
\text { undergrowth, like a soil } \\
\text { cover plant in the shade }\end{array}$ \\
\hline
\end{tabular}




\begin{tabular}{|c|c|c|c|}
\hline $\begin{array}{l}\text { Haskap - } \\
\text { Lonicera } \\
\text { caerulea L. }\end{array}$ & $\begin{array}{l}\text { Early varieties: } \\
\text { Altair, Goluboye } \\
\text { vereteno } \\
\text { Medium varieties: } \\
\text { Nimfa, Sinaya Ptitsa } \\
\text { Late varieties: } \\
\text { Leningradsky } \\
\text { Velikan }\end{array}$ & $\begin{array}{l}\text { Decorative: flower, fruit. } \\
\text { Vegetation - April - } \\
\text { September; } \\
\text { Flowering -March-April; } \\
\text { Fertility May - June; }\end{array}$ & $\begin{array}{l}\text { Single or in groups, to form } \\
\text { free hedges }\end{array}$ \\
\hline $\begin{array}{l}\text { Snowy } \\
\text { mespilus - } \\
\text { Amelanchie } \\
\text { r ovalis } \\
\text { Med. }\end{array}$ & $\begin{array}{l}\text { Moonlake, Nelson, } \\
\text { Regan, Slate, } \\
\text { Smoky }\end{array}$ & $\begin{array}{l}\text { Decorative: crown, leaf, } \\
\text { flower, fruit. } \\
\text { Vegetation - April - } \\
\text { October; } \\
\text { Blossoms - May } \\
\text { Fertility - June - July; }\end{array}$ & $\begin{array}{l}\text { As a middle tier in a group, } \\
\text { on the edges. } \\
\text { Solitaire, hedge, curtina, } \\
\text { group, ordinary landing. }\end{array}$ \\
\hline $\begin{array}{l}\text { Small } \\
\text { cranberry - } \\
\text { Vaccinium } \\
\text { oxycoccos } \\
\text { L. }\end{array}$ & $\begin{array}{l}\text { Alaya zapovednaya, } \\
\text { Dar Kostromy, } \\
\text { Krasa Severa, } \\
\text { Sazonovskaya, } \\
\text { Severyanka, } \\
\text { Sominskaya, } \\
\text { Hotavetskaya, } \\
\text { Pilgrim, } \\
\text { McFarlin, Ben Lear }\end{array}$ & $\begin{array}{l}\text { Decorative: leaf, flower, } \\
\text { fruit. } \\
\text { Vegetation -March- } \\
\text { October; } \\
\text { Blossoms - May } \\
\text { Fertility August; }\end{array}$ & $\begin{array}{l}\text { Group planting, soil cover } \\
\text { plant, imitation of "swamp." } \\
\text { Requires specially prepared } \\
\text { moistened, acidic, poor } \\
\text { soils }\end{array}$ \\
\hline $\begin{array}{l}\text { Northern } \\
\text { highbush } \\
\text { blueberry } \\
\text { Vaccinium } \\
\text { corymbosu } \\
m \text { L. }\end{array}$ & $\begin{array}{l}\text { Golubaya Rossyp’, } \\
\text { Divnaya, } \\
\text { Izyaschnaya, } \\
\text { Iksinskaya, Bluetta, } \\
\text { Bonus, Brigitta, } \\
\text { Nortland, Peka } \\
\text { Patriot, Pink } \\
\text { Lemonade }\end{array}$ & $\begin{array}{l}\text { Decorative: gabitus, } \\
\text { flower, fruit. } \\
\text { Vegetation - April - } \\
\text { September; } \\
\text { Blossoms - June; } \\
\text { Fertility - July; }\end{array}$ & $\begin{array}{l}\text { Group and solitary planting, } \\
\text { curtin, undergrowth of } \\
\text { conifers. } \\
\text { Requires acidic, drained, } \\
\text { well-fertilized soils }\end{array}$ \\
\hline $\begin{array}{l}\text { Lingonberr } \\
\text { y } \\
\text { Vaccínium } \\
\text { vítis-idaéa } \\
\text { L. }\end{array}$ & $\begin{array}{l}\text { Kostromychka, } \\
\text { Kostromskaya } \\
\text { Rozovaya, Rubin, } \\
\text { Runo Belawskie, } \\
\text { Erntesegen }\end{array}$ & $\begin{array}{l}\text { Decorative: leaf, flower, } \\
\text { fruit. } \\
\text { Vegetation -April- } \\
\text { October; } \\
\text { Blossoms - May } \\
\text { Fertility August; }\end{array}$ & $\begin{array}{l}\text { Group planting, soil cover } \\
\text { plant, imitation of "swamp." } \\
\text { Requires specially prepared } \\
\text { moistened, acidic, poor } \\
\text { soils }\end{array}$ \\
\hline $\begin{array}{l}\text { Guelder- } \\
\text { rose - } \\
\text { Viburnum } \\
\text { opulus L. }\end{array}$ & $\begin{array}{l}\text { Buldenej, Souzga, } \\
\text { Tayejnye Rubiny, } \\
\text { Jolobovskaya, } \\
\text { Zarnitsa, } \\
\text { Vigorovskaya }\end{array}$ & $\begin{array}{l}\text { Decorative: leaf, flower, } \\
\text { fruit. } \\
\text { Vegetation -April - } \\
\text { October. } \\
\text { Blossoms - May } \\
\text { Fertility September }\end{array}$ & $\begin{array}{l}\text { As a middle tier in a group, } \\
\text { on the edges. } \\
\text { Solitaire, hedge, curtina, } \\
\text { group, ordinary landing. }\end{array}$ \\
\hline
\end{tabular}

Sustainability and the prospect of the use of plants in urban landscaping is characterized by a set of important features and is expressed in the point assessment of each studied species. Comprehensive studies on 7 key features are presented in Table 2.

Many ornamental species of shrubs during observations we have almost no recorded damage from low temperatures, their shoots by the end of the growing season tree by 90 $100 \%$ and only in severe winters there is a dying of ends in late-vegetative shoots. This freezing of the tops of annual growths is caused by unstable winters with sharp fluctuations in temperature and thaws, which were observed in the years of research. However, the presented ornamental types of shrubs easily rise above-ground, annually bloom and bear fruit. 
Table 2. Integral assessment of the prospects of some ornamental types of garden shrubs.

\begin{tabular}{|l|c|c|c|c|c|c|c|c|c|c|}
\hline \multicolumn{1}{|c|}{ Species } & $\begin{array}{c}\text { Win } \\
\text { ter } \\
\text { resis } \\
\text { tanc } \\
\text { e }\end{array}$ & $\begin{array}{c}\text { Dro } \\
\text { ught } \\
\text { resis } \\
\text { tanc } \\
\text { e }\end{array}$ & $\begin{array}{c}\text { Resist } \\
\text { ance } \\
\text { to } \\
\text { pests } \\
\text { and } \\
\text { diseas } \\
\text { es }\end{array}$ & $\begin{array}{c}\text { Incr } \\
\text { ease }\end{array}$ & $\begin{array}{c}\text { Gen } \\
\text { erat } \\
\text { ive } \\
\text { deve } \\
\text { lop } \\
\text { men } \\
\text { t }\end{array}$ & $\begin{array}{c}\text { Sust } \\
\text { aina } \\
\text { biliy } \\
\text { in } \\
\text { crop }\end{array}$ & $\begin{array}{c}\text { De } \\
\text { cor } \\
\text { ati } \\
\text { ve } \\
\text { nes } \\
\text { s }\end{array}$ & $\begin{array}{c}\text { Poi } \\
\text { nts }\end{array}$ & $\begin{array}{c}\text { Ada- } \\
\text { ptati } \\
\text { on } \\
\text { ratio }\end{array}$ & $\begin{array}{c}\text { Per } \\
\text { spe } \\
\text { c- } \\
\text { tie } \\
\text { gro } \\
\text { up }\end{array}$ \\
\hline Cerasus vulgaris & 4 & 5 & 5 & 5 & 4 & 5 & 10 & 38 & 95,0 & 1 \\
\hline Cerasus fruticosa & 5 & 5 & 4 & 5 & 4 & 5 & 10 & 38 & 95,0 & 1 \\
\hline $\begin{array}{l}\text { Cerasus } \\
\text { tomentosa }\end{array}$ & 4 & 5 & 3 & 5 & 5 & 4 & 5 & 36 & 90,0 & 1 \\
\hline $\begin{array}{l}\text { Cerasus } \\
\text { glandulosa }\end{array}$ & 4 & 5 & 5 & 5 & 4 & 5 & 10 & 38 & 95,0 & 1 \\
\hline $\begin{array}{l}\text { Hippohae } \\
\text { rhamnoides }\end{array}$ & 4 & 5 & 4 & 5 & 5 & 5 & 10 & 38 & 95,0 & 1 \\
\hline $\begin{array}{l}\text { Grossularia } \\
\text { reclinata }\end{array}$ & 4 & 4 & 5 & 5 & 5 & 5 & 10 & 38 & 95,0 & 1 \\
\hline Ribes aureum & 5 & 5 & 5 & 5 & 5 & 5 & 10 & 40 & 100 & 1 \\
\hline $\begin{array}{l}\text { Ribes } \\
\text { americanum }\end{array}$ & 5 & 5 & 5 & 4 & 5 & 5 & 10 & 39 & 97,5 & 1 \\
\hline Ribes nigrum & 5 & 5 & 5 & 5 & 5 & 4 & 10 & 26,5 & 95,0 & 1 \\
\hline Ribes rubrum & 5 & 5 & 5 & 4 & 5 & 5 & 10 & 39 & 97,5 & 1 \\
\hline Rubus idaeus & 4 & 4 & 5 & 4 & 5 & 4 & 10 & 36 & 90,0 & 2 \\
\hline Rubus nigrum & 3 & 4 & 4 & 4 & 4 & 4 & 9 & 32 & 80,0 & 2 \\
\hline Rubus odorata & 4 & 5 & 4 & 4 & 4 & 4 & 10 & 32 & 80,0 & 2 \\
\hline Rubus arcticus & 4 & 4 & 4 & 4 & 4 & 4 & 8 & 32 & 80,0 & 2 \\
\hline Lonicera caerulea & 5 & 5 & 5 & 4 & 5 & 5 & 10 & 39 & 97,5 & 1 \\
\hline $\begin{array}{l}\text { Amelanchier } \\
\text { ovalis }\end{array}$ & 5 & 5 & 4 & 5 & 5 & 5 & 10 & 39 & 97,5 & 1 \\
\hline $\begin{array}{l}\text { Vaccinium } \\
\text { oxycoccos }\end{array}$ & 4 & 3 & 5 & 3 & 3 & 3 & 6 & 27 & 67,5 & 3 \\
\hline $\begin{array}{l}\text { Vaccinium } \\
\text { corymbosum }\end{array}$ & 4 & 4 & 5 & 3 & 3 & 4 & 7 & 30 & 75,0 & 3 \\
\hline $\begin{array}{l}\text { Vaccínium vítis- } \\
\text { idaéa }\end{array}$ & 4 & 3 & 5 & 3 & 3 & 3 & 6 & 27 & 67,5 & 3 \\
\hline Viburnum opulus & 5 & 4 & 5 & 5 & 5 & 5 & 10 & 39 & 97,5 & 1 \\
\hline
\end{tabular}

Thus, in the conditions of introduction in Moscow and the region shrubs are stable, the shoots of which do not freeze in winter and almost completely woodpbre down by the end of the growing season.

When introduced in the conditions of the metropolis of Moscow, the vital form of the studied plants is preserved the same as they grew in the natural area - shrubs [1-2, 7-9]. After exposure to negative environmental factors, the escaping ability of plants determines the preservation or restoration of the crown gabitus. Studies have shown that all species we study have a high shoots forming ability [10-12].

The most important indicator of the plant's life is its growth. The growth of shoots is a generalized complex indicator, synthesizing not only the results of the plant's organism, which accumulates a complex effect on plants of the environment. The development and growth of shrubs is the most important indicator of plant adaptation in the introduction to new geographical areas [13-17]. Observations showed that all the samples studied had an 
annual increase in shoots of between $9 \mathrm{~cm}$ and $1.3 \mathrm{~m}$, which was due to the potential rate of bush growth.

The success of introduction is revealed as well as their reproductive ability. The formation of viable fertile seeds in plants indicates their sufficient adaptability to the environment in the metropolis. The production of viable seeds, which determine the development of sustainable seed generations, ensures that plants survive and spread in new conditions. Observations carried out in Moscow, revealed annual fruiting and the formation of viable seeds in all the species studied. As a result, the adaptation rate of the studied species of shrubs was divided by our degree of perspective into three groups. The most promising group consisting of $65 \%$ of the samples was the first, whose representatives were characterized by high winter resistance and ability to full-fledged seed reproduction, decorativeness.

The average second group includes $20 \%$ of the samples studied. This includes plants that during the growing season retain ornamentality, capable of breeding seeds, but they are less promising than representatives of the 1 st group, due to the inability to maintain ornamentality in the growing season and do not give offspring self-seeding.

The third group was not a promising group, which included $15 \%$ of the samples. Species of shrubs, belonging to this group of enough winter-resistant, have the ability to seed reproduction, but were not promising due to high requirements for soil growing conditions and not high decorative qualities in the conditions of the metropolis.

However, seed reproduction of crops is the longest and most promising breeding method for these crops. Even with the traditional method of vegetative reproduction, it is impossible to quickly obtain the planting material in the right quantity and appropriate quality.

Now there are new and continue to improve promising high-tech ways of vegetative reproduction of garden crops, including not only the acceleration of breeding technology, but also the recovery of planting material, at the same time as the high output of the planting material and the high breeding rate, superior to the seed and traditional vegetative method of reproduction. This accelerated breeding technology allows to fully preserve the varietal and decorative qualities of breeding plants.

Table 3. Timeline of receipt of the planting material of berry shrubs by microclonal reproduction technology for the period from introduction to the end of adaptation, weeks.

\begin{tabular}{|l|c|c|c|c|c|}
\hline Crop & Introduction & Reproduction & Rooting & Adaptation & $\begin{array}{l}\text { Total } \\
\text { weeks }\end{array}$ \\
\hline Rubus (Raspberry) & 6 & 6 & 3 & 4 & 19 \\
\hline Rubus (Blackberry) & 6 & 6 & 3 & 4 & 19 \\
\hline $\begin{array}{l}\text { Grossularia } \\
\text { (Gooseberry) }\end{array}$ & 6 & 8 & 3 & 4 & 21 \\
\hline Ribes (Currant) & 4 & 8 & 3 & 3 & 18 \\
\hline Vaccinium (Blueberry) & 12 & 8 & 6 & 6 & 32 \\
\hline
\end{tabular}

According to Table 3, it can be concluded that the earliest time to obtain a planting material on accelerated technology is characterized by currants (18 weeks), raspberries and blackberries (19 weeks), longer in the time it takes to grow gooseberries - 21 weeks. The longest time (32 weeks) and the specific breeding process in blueberries, requiring strict adherence to all parameters.

For most of the studied cultures at the introduction stage used the environment MS (raspberry, blackberry, currant), for gooseberry - environment Lp, for blueberries - WPM environment. Almost all stages of reproduction require the addition of hormones: BAP, IAA in different concentrations and depending on culture. 
For microclonal reproduction of raspberries and blackberries used the MS environment with the addition of BAP (mg/L) at the injection stage -0.8; Breeding - 0.7; Rooting was carried out on Wednesday 1/2 MS with the addition of IAA - 0.4 . For the reproduction of currants used the MS environment with the addition of VAR $(\mathrm{mg} / \mathrm{L})$ at the stage of introduction -0.4 ; breeding - 0.7 with the addition of IAA -0.1 ; rooting was carried out on the environment without hormones. For gooseberry used Lp environment with the addition of BAP (mg/l) at the injection stage -0.4; breeding - $0.2-0.4$; 0.1 or without hormones. For blueberries used WPM environment with the addition of IP 5000 at the stages of introduction and reproduction, rooting was carried out on the environment without hormones.

When using these types of plants for urban landscaping, it is necessary to comply with the appropriate regulations for the greening of public spaces, squares, boulevards, gardens and parks. In particular, the use of bewitched species, with poisonous leaves, flowers and fruits, as well as plants that are strongly affected by diseases and damaged by pests are not allowed.

In the presented variety there are species containing thorns and thorns on shoots, such as gooseberry, buckthorn, raspberries, but the variety is selected in such a way that it includes varieties with little or no thorns and thorns (table 1).

Almost all crops do not require special soil preparation for most crops, the exception is representatives of the Family of Heather (cranberries, cranberries, blueberries), requiring special poor, loose, acidic and moisturized soils.

Most species have ornamental flowers, inflorescences and small, bright edible fruits. With small sizes and the number of fruits excluded damage coatings, bad smell in the fall of fruits and the desire of visitors to gardens and parks to use them in fresh form.

For some crops, which are popular fruit or berry crops (cherry, currant, raspberries), characteristic of frequent damage to pests and diseases in the absence of proper care. But it is not necessary to abandon them for the purposes of urban landscaping, as they give landscapes a special attraction and carry an important practical wash - it is the popularization of knowledge about such cultures in the population. To maintain the decorativeness of such plants, it is necessary to carry out regular pruning, formation, preventive treatment and agrotechnical techniques.

Thus, the presented assortment of shrubs is promising for urban landscaping. The use of these crops will expand the traditional range of shrubs for urban landscaping, together with ornamental trees they will create high-decorative plantings. With appropriate care and the level of agricultural engineering, the recommended species will look decorative, while also performing an important information and learning function.

\section{Findings}

1. The shrub species studied are divided by the degree of adaptation by degree of perspective into three groups.

2. The most promising group is the first - $65 \%$ of species (Cerasus vulgaris Mill., Cerasus fruticosa Pall., Cerasus tomentosa (Thunb.) Wall., Cerasus glandulosa (Thunb.) Loisel., Hippohae rhamnoides L, Grossularia reclinata (L.) Mill., Ribes aureum Pursh, Ribes americanum Mill., Ribes nigrum L., Ribes rubrum L.), whose representatives are characterized by high winter resistance and the ability to full-fledged seed and vegetative reproduction, decorativeness.

3. Medium-promising second group - includes $20 \%$ of the species studied (all Rubus species).

4. The third group is not a promising group, includes $15 \%$ of samples (Vaccinium oxycoccos L., Vaccinium corymbosum L., Vaccínium vítis-idaéa L.), which are not 
promising due to high requirements for soil conditions and not high decorative qualities in the metropolis.

5. The technology of accelerated reproduction of berry crops has been developed. The timing of the planting material was 18 to 32 weeks. The following crops are particularly important: raspberries, blackberries, currants, gooseberries, 18-21 weeks.

6. Elements of accelerated clonal breeding of berry crops for urban landscaping have been worked out and improved.

\section{References}

1. Ivanova I.V., Ponomaryova U.G., Hanbabaeva O.E. Dekorativnoe sadovodstvo. Tutorial. Moscow. 2014. 146 p.

2. Ivanova I.V., Hanbabaeva O.E. Kamenisty sad. Tutorial. Moscow. 2012. 123 p.

3. Kovaleva I.S., Matsneva A.E., Ханбабаева O.E., Mazaeva A.S. Vvedenie v kulturu in vitro i klonalnoe mikrorazmnojenie perspectivnogo seyantsa smorodiny chyornoy (Ribes nigrum L.)/ Vestnik KrasSAU. 2019. №12 (153). P.43-48. DOI: 10.36718/18194036-2019-12-43

4. Selehov A.N., Hanbabaeva O.E. Kompleksnaya otsenka tsvetochnogo oformleniya goroda Moskvy// Vestnik landshaftnoy arhitectury.2014. №4.P. 67-71.

5. Selehov A.N., Hanbabaeva O.E. Optimizatsiya metodiki anketirovaniya M.U. Frolovoy dlya analiza predpochteniy $\mathrm{v}$ tsvetochnom oformlenii gorodskih parkov Mokvy// Vestnik landshaftnoy arhitectury. 2015. №5. P. 72-77.

6. Skakova A.G., Hanbabaeva O.E. Proektirovanie spetsializirovannyh objektov landshaftnoy arhitectury // Teaching manual. - Moscow, 2018. 124 p.

7. Hanbabaeva O.E. Multimedijnoe uchebnoe posobie «Dekorativnaya dendrologiya. Pokrytosemennye rasteniya». Svidetelstvo o registracii bazy dannyh RU 2013620649. Zayavka № 2013620365 от 17.04.2013.

8. Hanbabaeva O.E. Dekorativnye drevesnye kultury v dizajne sada. Monografiya. Izd-vo MESH. Moskva, 2018., 132 p.

9. Sorokopudov V.N., Martynova N.A., Shirina L.S., Shevchenko S.M. Integralnaya ocenka perspektivnosti novyh sortov zhimolosti alpijskoj v usloviyah Belgoroda // Subtropicheskoe i dekorativnoe sadovodstvo. 2015. № 55. P. 73-78.

10. Burmenko U.V., Sorokopudov V.N., Shlapakova S.N., Nigmatzyanov R.A. Vozmozhnosti ispolzovaniya smorodiny zolotistoj (Ribes aureum Pursh) v kachestve obekta landshaftno-parkovogo stroitelstva // Vestnik Hakasskogo gosudarstvennogo universiteta im. N.F. Katanova. 2015. № 13. P. 50-51.

11. Sorokopudov V.N., Burmenko U.V., Nigmatzyanov R.A. Perspektivy selekcii smorodiny zolotistoj // Vestnik hakasskogo gosudarstvennogo universiteta im. N.F. Katanova. 2015. № 13. P. 93-95.

12. Sorokopudov V.N., Kuklina A.G., Shlapakova S.N. Dekorativnye vidy zhimolosti dlya ozeleneniya naselyonnyh punktov // Vestnik Hakasskogo gosudarstvennogo universiteta im. N.F. Katanova. 2015. № 13. C. 95-97.

13. Arestova E.A. Integralnaya ocenka perspektivnosti rastenij roda Sorbus L. v dendrarii NIISH yugo-vostoka // Lesnoe hozyajstvo Povolzhya. - Saratov, 2002. Vol. 5. - P. 98 102.

14. Karpun U.N. Osnovy introdukcii rastenij // Sohranenie i mobilizaciya geneticheskih resursov v botanicheskih sadah. - Sochi, 2004. Vol. 2. - P. 17 - 32.

15. Kolesnikov A.I. Dekorativnaya dendrologiya / A.I. Kolesnikov. - M.: Lesnaya promyshlennost, 1974. - $704 \mathrm{p}$. 
16. Lapin P.I., Ryabova-Stogova N.V. Ocenka perspektivnosti introdukcii zhimolosti po dannym vizualnyh nablyudenij // Byul. GBS. M.: Nauka, 1977.- Vol. 103. - P. 12-18.

17. Plotnikova L.S. Nauchnye osnovy introdukcii i ohrany drevesnoj rastitelnosti flory SSSR / L.S. Plotnikova. - M.: Nauka, 1988. - 264 p. 